\title{
PROGRAM PENGABDIAN: SOSIALIASI BAHAYA KEBAKARAN MENGGUNAKAN PROTOTYPE ALAT BERBASIS IOT UNTUK WARGA HINTERLAND BATAM
}

\author{
Dwi Ely Kurniawan ${ }^{1}$, Ahmad Hamim Thohari ${ }^{2}$ \\ ${ }^{1,2}$ Jurusan Teknik Informatika \\ Politeknik Negeri Batam \\ Email: dwialikhs@polibatam.ac.id ${ }^{1)}$,hamim@polibatam.ac.id ${ }^{2)}$
}

\begin{abstract}
The dry season is starting to be felt in Batam and brings the threat of drought. This dry or hot season has an impact in the form of the threat of protected forest fires in the Rempang and Galang Island areas, Batam. Residents of Pasir Panjang at the end of last month a fire accident occurred in the residential area of the village. This has made residents wary of fires. The development of technology is currently increasing rapidly with the existence of the Internet of Thing (IOT) which is one of the solutions to problems in daily activities, including in handling fires. The purpose of this service is to try to make an application for fire detection in the residential area. The method of implementation is carried out in stages, needs analysis, training and mentoring programs, handing over of tools and evaluation of activities. The results of this service are in the form of a prototype IoT application product. Another result is from training in the form of socialization of fire hazard prevention by demonstrating a tool with a very good and enthusiastic response from the community based on an average rating scale above 4.
\end{abstract}

Kata kunci : IoT, fire, fire extinguisher, Batam

\begin{abstract}
Abstrak. Musim kemarau mulai terasa di Batam dan membawa ancaman kekeringan. Musim kemarau atau panas ini menimbulkan dampak berupa ancaman kebakaran hutan lindung di kawasan Pulau Rempang dan Galang, Batam. Warga Pasir Panjang akhir bulan lalu terjadi musibah kebakaran yang menimpa di kawasan perkampungan tempat tinggal. Hal ini membuat warga was-was terhadap bancana kebakaran. Perkembangan teknologi saat ini semakin pesat dengan adanya Internet of Thing (IOT) menjadi salah satu pemecahan masalah dalam aktifitas sehari-hari, tak terkecuali dalam penanganan kebakaran. Tujuan dari pengabdian ini adalah mencoba membuat suatu aplikasi untuk pendeteksi kebakaran di daerah perkampungan tempat tinggal. Metode pelaksanaan dilakukan secara bertahap analisa kebutuhan, program pelatihan dan pendampingan, penyerahan alat dan evaluasi kegiatan. Hasil pengabdian berupa produk prototype aplikasi IoT. Hasil lain yakni dari pelatihan berupa sosialisasi pencegahan bahaya kebakaran dengan memperagakan alat dengan respon masyarakat sangat baik dan antusias berdasarkan rata2 penilaian skala diatas 4 .
\end{abstract}

Keywords: IoT, kebakaran, pemadam api, Batam

\section{PENDAHULUAN}

Musim kemarau mulai terasa di Batam dan membawa ancaman kekeringan. Lebih dari itu, musim panas juga menimbulkan dampak lain berupa ancaman kebakaran hutan lindung di kawasan Pulau Rempang dan Galang (Relang) serta Galang Baru di Kecamatan Galang, Batam, Kepulauan Riau (Kepri). Zubair, 42, warga desa Monggak, Kelurahan Rempang Cate, Kecamatan Galang mengatakan, di kampungnya sudah terjadi dua kali kebakaran. Kebakaran yang menghanguskan beberapa hektare lahan hutan itu cukup membuat warga panik. Salah satunya sempat memghanguskan rumah kosong di pinggir kampung. Selain itu Jaka Alamsyah, 26, warga,
Desa Sembulang, Kecamatan Galang. Penanganan kebakaran di wilayah kampungnya bahkan sudah melibatkan pihak kepolisian. Kerawanan ini hendaknya sama-sama diperhatikan semua pihak (Jawa Pos), (Tribun Batam).

Masyarakat yang berada di Kampung Sememal RT.001 RW 001 Kelurahan Pasir Panjang Kecamatan Meral Barat Kabupaten Karimun mendadak dihebohkan dengan kebakaran yang menimpa di perkampungan tempat tinggal (Tribun Batam). Kebakaran yang menimpa tersebut diketahui terjadi pukul 11.00 WIB siang, Selasa 6 Maret 2018. Dugaan penyebab kebakaran adalah konsleting listrik. 

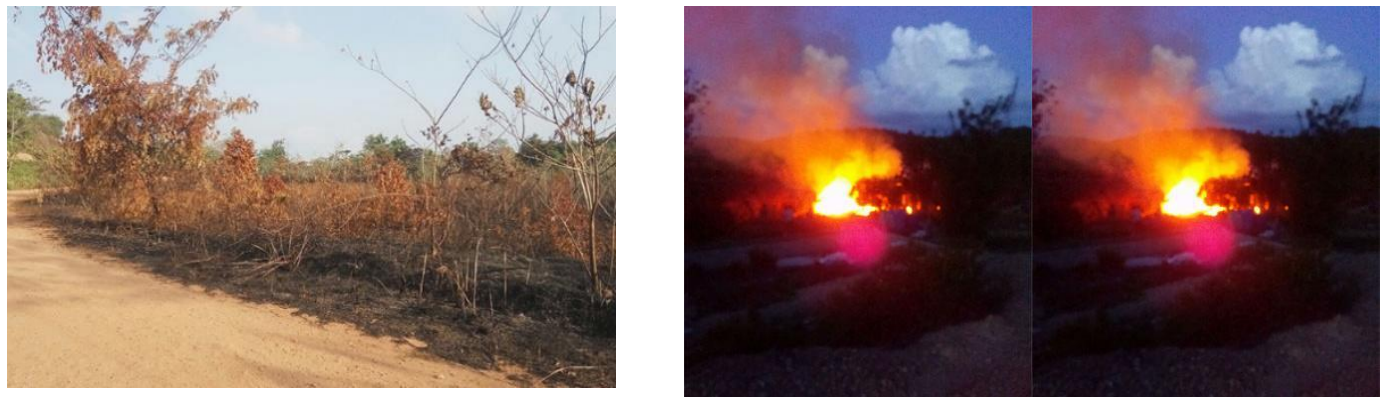

Gambar 1. Kebakaran Hutan Lindung di Kelurahan Rempang Cate, Galang, Batam (sumber: Jawa Pos dan Tribun Batam)
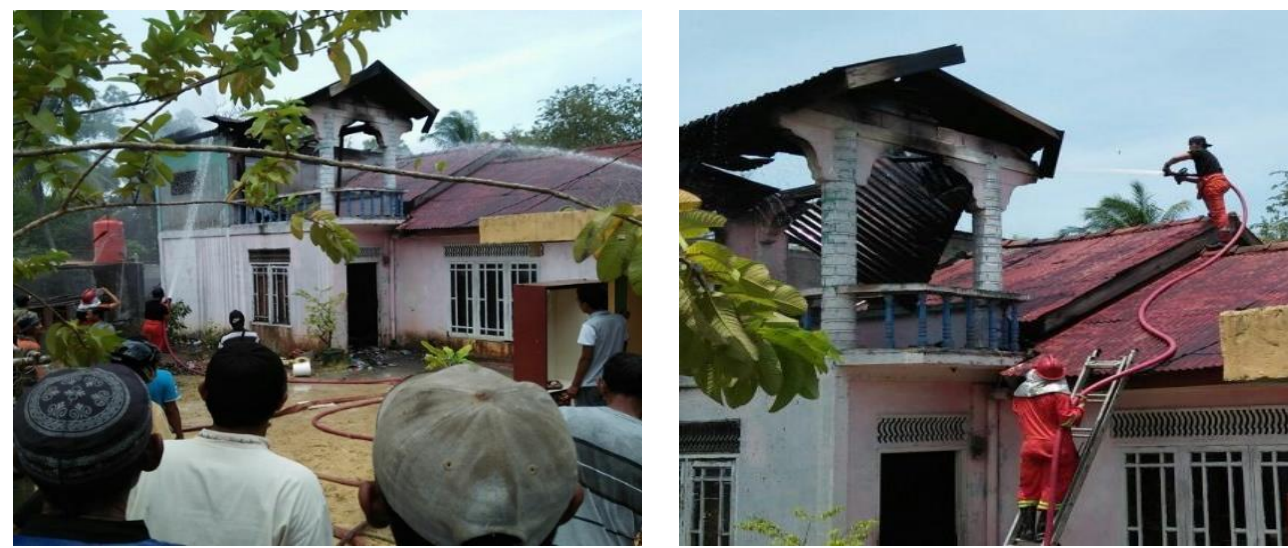

Gambar 2. Susasana kebakaran di perkampungan dan penanganan kebakaran oleh Damkar (sumber: Kepri Online, Tribun Batam)

Petugas Pemadam Kebakaran (Damkar) Barelang, Zabri mengatakan, sampai saat ini sudah berupaya menanggulangi ancaman kebakaran di wilayah hutan lindung tersebut. Pihaknya juga sudah mendata adanya sejumlah titik titik api di wilayah Rempang tersebut. Penyebab kebakaran ini terjadi adanya oknum yang sengaja atau pun tidak sengaja membakar hutan. Hal ini dimungkinkan karena dengan membakar hutan dapat membuka lahan dengan mudah dan murah (Kepri Online). Pihak Damkar sudah mendata beberapa titik api di Kampung Baru, Rempang Cate.

Perkembangan teknologi saat ini telah berkembang pesat. Internet of Thing (IOT), memungkinkan untuk menjadi salah satu solusi dalam penanganan kebakaran. Beberapa peneltian yang telah mengembangkan diantaranya pendeteksi kebakaran berbasis IOT menggunakan Arduino dan SMS gateway untuk pengiriman informasi kebakaran (Sasmoko et al., 2017), sensor wireless sebagai monitoring pendeteksi kebakaran hutan (Sirait, et al., 2016), WSN untuk mendeteksi dini potensi kebakaran
(Irawan, et al., 2017) (Hakim et al., 2012). Pengabdian ini mencoba untuk membuatkan suatu aplikasi yang mampu mendeteksi kebakaran. Hasil dari pengabdian nantinya berupa program pelatihan dan pendampingan dalam penanganan kebakaran serta pentingnya penghijauan di Desa Pasir Panjang, Kelurahan Rempang Cate, Batam baik untuk pemukiman atau hutan lindung disekitarnya.

Berdasarkan wawancara dan analisis situasi dapat disimpulkan permasalahan mitra yang muncul adalah sebagai berikut:

a) Penanganan musibah kebakaran hutan masih belum mampu ditangani secara sungguh-sungguh oleh warga dan semua pihak yang berkepentingan

b) Belum adanya pemahaman yang baik terhadap hutan sebagai ekosistem yang harus dijaga bersama untuk kehidupan. Hal ini terlihat ada beberapa oknum yang sengaja membakar hutan. 
c) Kurangnya keterampilan dalam penanganan sejak dini terhadap penanganan kebakaran.

d) Masyarakat masih menganggap kebakaran menjadi tanggung jawab pemerintah, petugas pemdam kebakaran (Damkar) bukan tanggung jawab bersama untuk dapat mengatasi kebakaran. Selain itu belum adanya kesadaran bersama. Hal ini terlihat bahwa mereka sering berfikir praktis untuk membuka lahan dengan mudahnya adalah membakar sawah atau lahan kebun yang mereka miliki.

Teknik Informatika Politeknik Negeri Batam mencoba melakukan kegiatan applied program pengabdian yang sesuai dengan permasalahan mitra. Berikut tujuan yang hendak dicapai dalam program pengabdian antara lain: a) Mengembangkan prototipe alat pendeteksi kebakaran di hutan lindung maupun perkampungan

b) Memberikan edukasi; pelatihan dan sosialisasi tentang manfaat hutan lindung, penanganan kebakaran, dan pemanfaatan TIK dalam kebakaran

c) Menjalin kerjasama sebagai desa binaan dari Politeknik Negeri Batam.

Peran mitra dalam kegiatan ini adalah menyediakan waktu, tempat dan bersedia untuk ikut terlibat dalam kegiatan pelatihan dan program pendampingan secara berkelanjutan. Mitra juga menyediakan konsumsi seadanya untuk menunjang kegiatan pengabdian.

\section{METODE PELAKSANAAN}

Metode pelaksanaan dalam program pengabdian masyarakat meliputi tahap persiapan, tahap pelaksanaan dan tahap evaluasi.

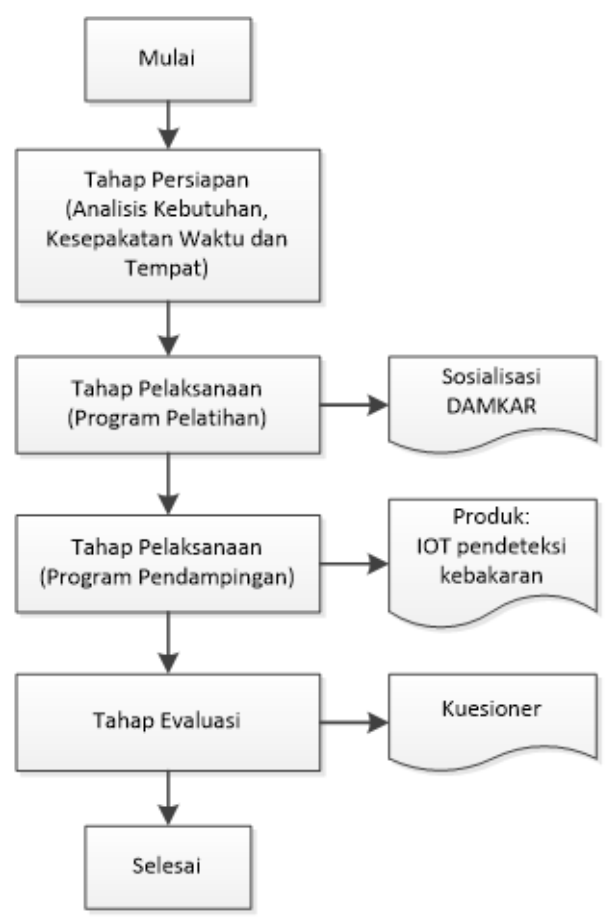

Gambar 3. Metode Pelaksanaan Pengabdian

Tahap persiapan membuat kesepakatan untuk mengalokasikan waktu dan tempat selama program pelatihan dan pendampingan. Selain itu menganalisis kebutuhan dengan melihat spesifikasi perangkat yang sudah ada dan sistem yang sudah berjalan. Metode pelaksanaan dalam program pengabdian masyarakat meliputi tahap persiapan, tahap pelaksanaan dan tahap evaluasi. Tahap persiapan membuat kesepakatan.

Adapun tahapan pelaksanaan yang telah dilaksanakan sampai saat ini: 
1) Kordinasi dengan dinas pemadam kebakaran sebagai pemateri dalam pelatihan

2) Perancangan prototipe alat pendeteksi kebakaran dengan melibatkan tim pengabdi dan mahasiswa

3) Survei ke lokasi desa pasir panjang

4) Pelatihan dan sosialisasi kepada masyarakat tentang manfaat hutan lindung

5) Pelatihan dan sosialisasi kepada masyarakat tentang pencegahan dan penanganan kebakaran

6) Pelatihan dan sosialisasi tentang pemanfaatn TIK dalam penanganan kebakaran

7) Pembuatan prototipe alat deteksi kebakaran sebagai edukasi dalam pemanfaatan TIK bagi masyarakat.

\section{HASIL DAN PEMBAHASAN}

\section{A. Program Edukasi Bahaya Kebakaran oleh Damkar}

Pelatihan dan sosialisasi kepada masyarakat dilaksanakan pada tanggal 20 Oktober 2018 di Desa Pasir Panjang Kelurahan Rempang Cate Kecamatan Galang. Pelatihan dimulai dari jam 13.00 WIB sampai jam 15.30 WIB. Pemateri dalam kegiatan ini adalah: Bapak Raja Ilham - Inspektur 1 Dinas Pemadam Kebakaran Kota Batam. Menyampaikan materi: penyebab kebakaran, pencegahan kebakaran di rumah, cara penanganan awal kebakaran, pencegahan kebakaran hutan lindung dan penggunaan alat pemadam api ringan (APAR)
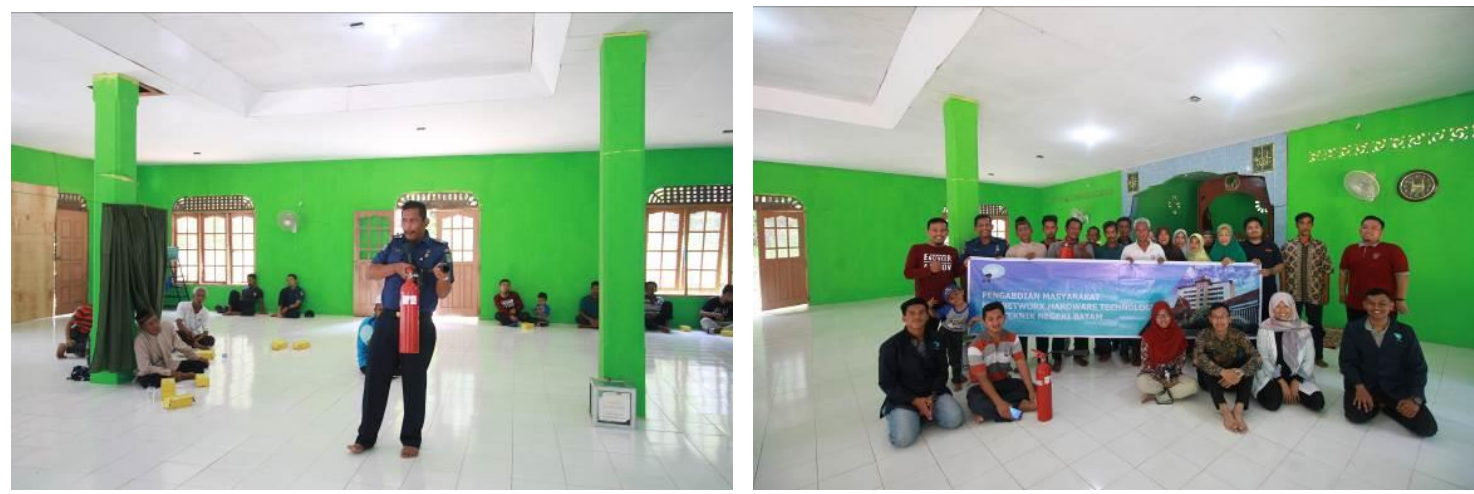

Gambar 4. Pengenalan Alat Pemadam Api Ringan (APAR) oleh Dinas Pemdam Kebakaran Kota Batam

Kegiatan sosialisasi ini telah dipublikasikan pada surat kabar Haluan Kepri baik cetak maupun online (https://www.haluankepri.com/news/detail/11629 2/polibatam-sosialisasi-bahaya-kebakaran).

Beberapa pesan materi dalam sosialisasi dan pelatihan tersebut untuk kasus kebakaran yang terjadi pada umumnya sebagai berikut.

1) Perbaiki steker listrik yang kendor/longgar, bertumpuk menyebabkan kabel menjadi panas dan mudah terbakar.

2) Tabung gas, bila tercium bau gas maka sebaiknya cabut regulator gas dan buka ventilasi atau pintu agar gas dapat keluar.
Apabila telah terjadi kebakaran gas dapat gunakan handuk yang telah dibasahi air untuk memadamkan api tersebut. Jangan sekali-kali menggunakan air untuk memadamkan api pada kebakaran gas.

3) Bila terjadi kebakaran pada genset sebaiknya gunakan pasir basah sebagai pemadam api, atau kain basah yang cukup untuk dapat memadamkan api.

4) Hati-hati dan waspada terhadap obat nyamuk, lilin dan rokok yang seharusnya ditempatkan sesuai pada tempatnya.

5) Siapkan Alat Pemadam Api Ringan (APAR) yang siap pakai di lingkungan kerja atau di rumah dan gunakan bila 
sewaktu-waktu diperlukkan untuk memadamkan api.

\section{Polibatam Sosialisasi Bahaya Kebakaran}

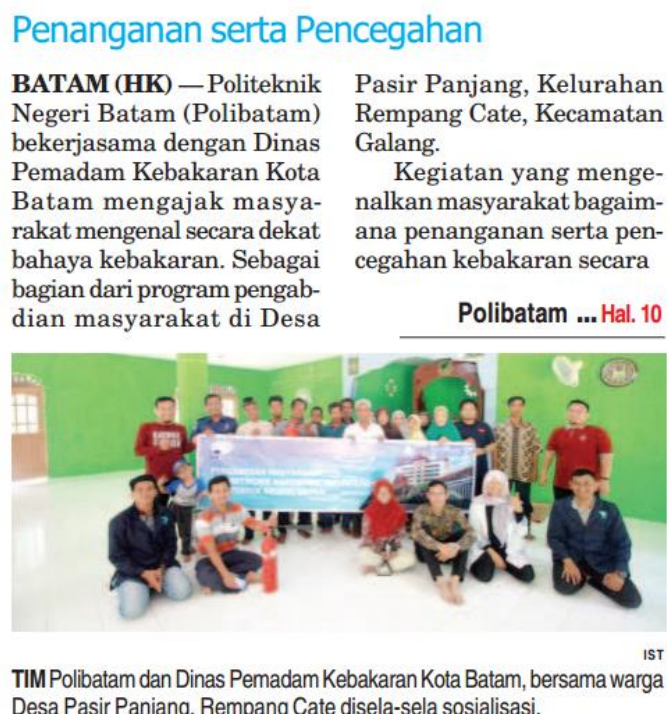

Polibatam Sosialisasi ....

sambungan Hal. 9

\begin{tabular}{|c|c|c|}
\hline $\begin{array}{l}\text { rakat setempat. } \\
\text { "Sosialisasi } \\
\text { ran ini terlaks } \\
\text { Dinas Pemada } \\
\text { Kota Batam d } \\
\text { Pasir Panjang. } \\
\text { batam ini meru } \\
\text { pengabdian ke } \\
\text { ungkap Koordin } \\
\text { Dwi Ely Kurniav } \\
\text { ri Polibatam, Sa } \\
\text { di Masjid Pasir } \\
\text { Sosialisasi p } \\
\text { haya kebakaran } \\
\text { lanjutnya, kar } \\
\text { merupakan mus } \\
\text { gat merugikan } \\
\text { dan imateril. S } \\
\text { kejadian bebera }\end{array}$ & $\begin{array}{l}\text { butannya menyata- } \\
t \text { antusias dengan } \\
\text { iatan tersebut, ter- } \\
\text { a Pasir Panjang be- } \\
\text { ktu yang lalu juga } \\
\text { rjadi musibah ke- } \\
\text { an warga tidak me- } \\
\text { gimana penanganan } \\
\text { ar, apalagi lokasi } \\
\text { dari pos pemadam }\end{array}$ & $\begin{array}{l}\text { alam sosialisasi tersebut dis- } \\
\text { mpaikan mengenai peta wi- } \\
\text { ayah Indonesia yang berpoten- } \\
\text { i bencana gempa bumi teruta- } \\
\text { na wilayah Kepri dan Kota } \\
\text { Batam dan pulau sekitarnya. } \\
\text { Kepri termasuk wilayah } \\
\text { ang tidak dilalui patahan dan } \\
\text { ecil kemungkinan terjadi gem- } \\
\text { a, namun demikian masya- } \\
\text { akatjuga perlu waspada untuk } \\
\text { nengantisipasi potensi benca- } \\
\text { la lainnya. (r/ays) }\end{array}$ \\
\hline
\end{tabular}

Gambar 5. Haluan Kepri 5 November 2018

B. Program Edukasi Prototype Alat beberapa ciri dari kebakaran seperti gas Pemadam Kebakaran

monoksida, karbon dioksida, perubahan suhu karena panas api dan sebagainya. Untuk pendeteksi gas, digunakan sensor MQ6 untuk

\section{Alat dan Bahan}

Prototipe alat dibuat dengan menggunakan beberapa bahan seperti:

1) Raspberry Pi Set with power supply

2) Gas Sensor MQ6

3) Temperatur Sensor LM 35

4) Temperatur Sensor DS18B20

5) Kabel dupont male - male $20 \mathrm{~cm}$

6) Kabel dupont male - female $20 \mathrm{~cm}$

7) Kabel dupont female - female $20 \mathrm{~cm}$

8) PCB dotmatrix

9) Project Board

10) Buzzer

11) Node MCU V3

12) Modul GSM Sim800L

13) Modul GPS NEO6M

\section{Cara Kerja Prototipe}

Prototipe perangkat ini menggunakan beberapa komponen sensor yang dirangkai sedemikian rupa sehingga dapat melakukan deteksi terhadap mendeteksi gas butane, propane, LPG dan LNG, serta sensor temperature LM 35 dan sensor DS18B20 untuk mengetahui perubahan suhu sekitar yang kemungkinan disebabkan oleh panas api. Setiap sensor dipasang menggunakan project board dan dikoneksikan ke raspberry pi 3 (Kurniawan et al., 2019) menggunakan kabel jumper male to male atau male to female atau kabel female to female sesuai dengan input dan output konektor yang terdapat pada masing masing sensor. Sebagai pemberi informasi kepada masyarakat sekitar digunakan buzzer yang akan bekerja ketika sensor mendeteksi gejala gejala yang menandakan bahwa di lokasi tersebut kemungkinan terjadi sebuah kebakaran. Selain itu digunakan pula modul GSM untuk memberikan update informasi yang diterima oleh sensor dan modul GPS untuk memberikan info akurat dimana lokasi dari sensor atau kebakaran itu terjadi. 

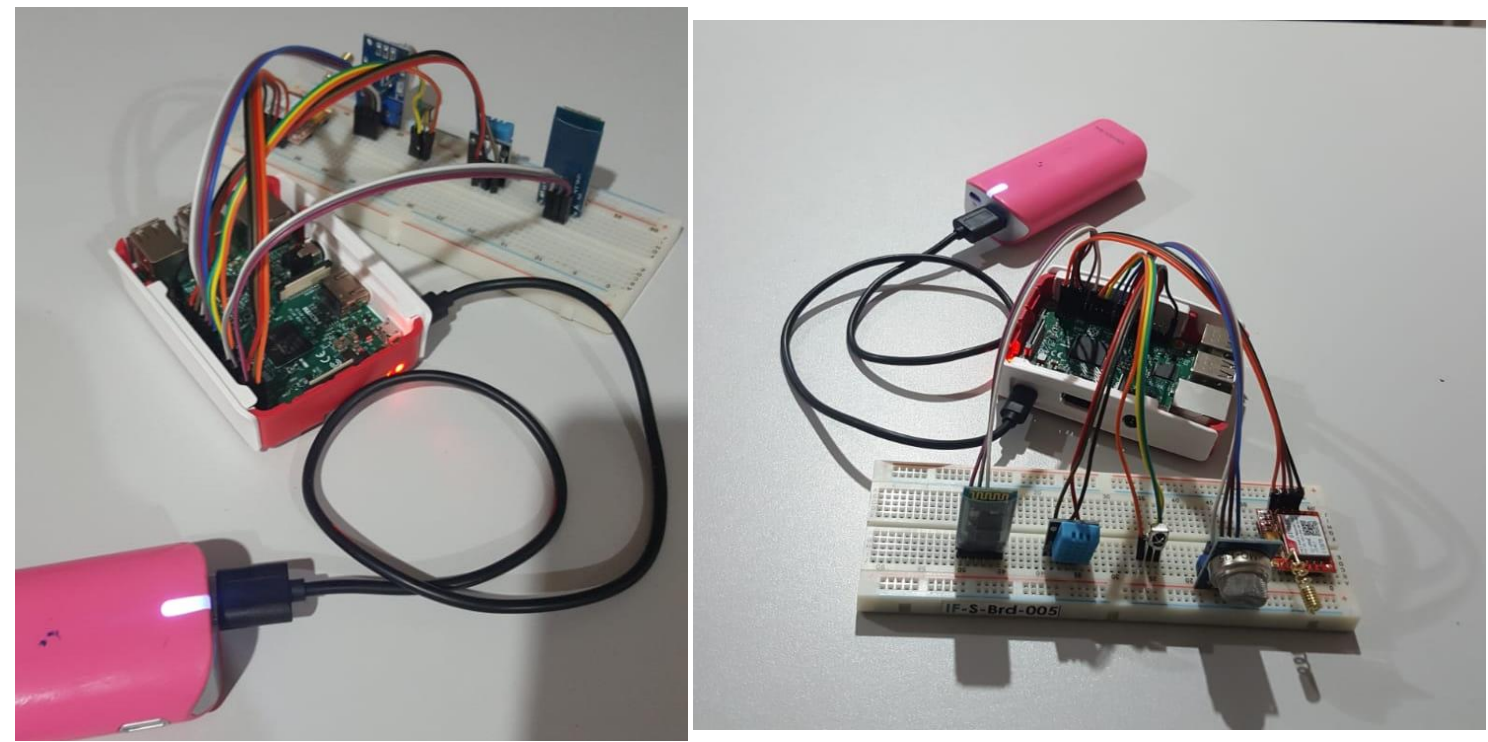

Gambar 6. Protoype Alat Pemadam Kebakaran

\section{Evaluasi Kegiatan}

Evaluasi kegiatan dilakukan dengan menyebarkan kuesioner untuk melihat hasil pengabdian bagi masyarakat. Beberapa aspek yang menjadi parameter evaluasi antara lain:

1) Aspek penyelenggaraan kegiatan pelatihan meliputi suasana, kelengkapan alat bantu, ketepatan waktu dan tema

2) Aspek pembicara (narasumber) meliputi teknik penyampaian materi, kompetensi pembicara dan kesesuaian materi yang disampaikan dengan kondisi masyarakat

3) Aspek pendukung lainnya seperti alat (prototype), konsumsi dan kejelasan sound system yang digunakan

Evaluasi pertanyaan menggunakan skala likert sebagai berikut.
1) Nilai 5 merepresentasikan Baik Sekali

2) Nilai 4 merepresentasikan Baik

3) Nilai 3 merepresentasikan Cukup

4) Nilai 2 merepresentasikan Kurang

5) Nilai 1 merepresentasikan Sangat Kurang

Seluruh peserta pelatihan diberikan kuesioner, namun demikian tidak semua peserta bersedia mengisi kuesioner. Total responden yang didapatkan adalah 20 orang warga. Respon dari warga terhadap aspek penting dalam kuesioner dikalkulasi dan rata-ratakan sehingga didapatkan hasil sebagaimana dapat dilihat pada Gambar 7.

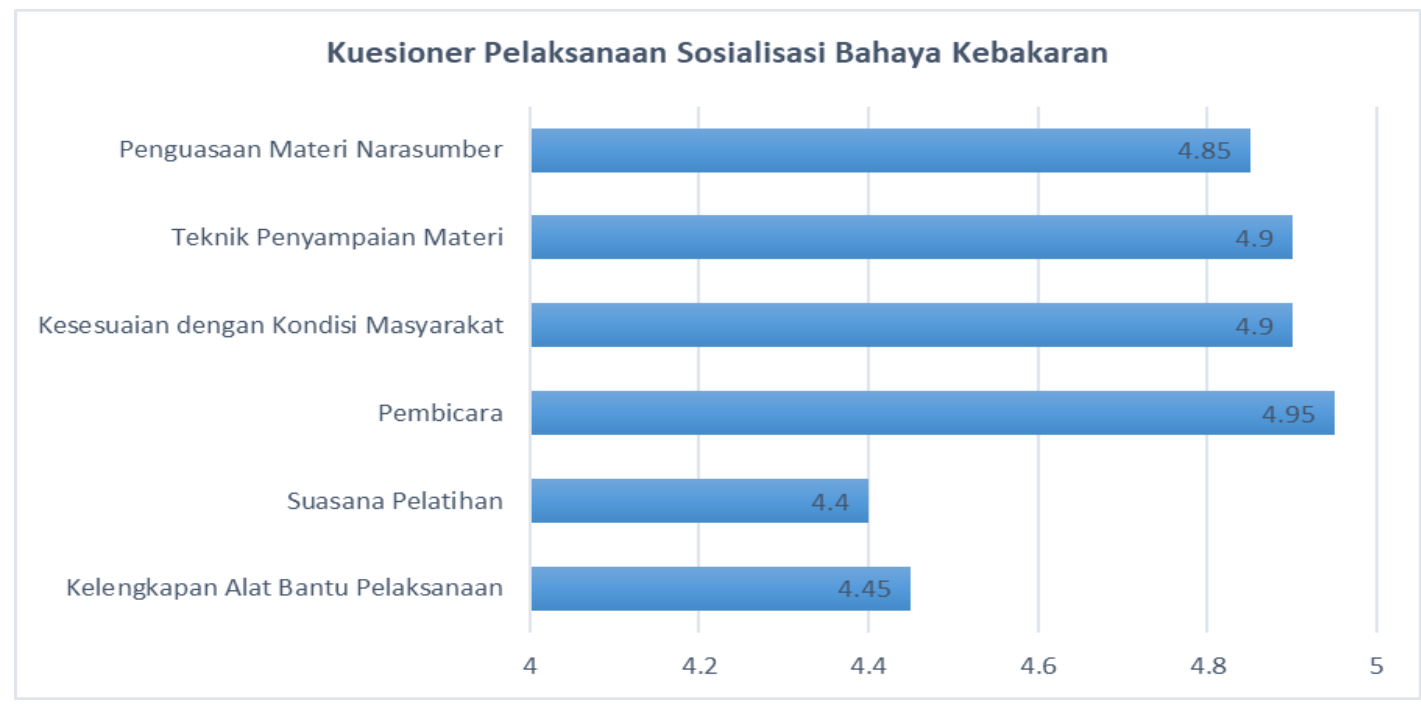

Gambar 7. Kuesioner Respon Warga Terhadap Pelaksanaan Pelatihan 
Berdasarkan hasil kuesioner respon warga terhadap pelaksanaan kegiatan pengabdian sangat baik dengan skala diatas 4. Ditemukan suasana pelatihan dan kelengkapan alat bantu pelaksanaan yang memang kurang memadai dengan jumlah warga yang ada. Namun mereka sangat antusias dalam ikut berpartisipasi dalam kegiatan pengabdian.

\section{SIMPULAN DAN SARAN}

Program pengabdian telah terlaksana dengan sosialisasi dan edukasi terhadap bahaya kebakaran. Hasil kuesioner evaluasi pelaksanaan berupa kuesioner dari sisi narasumber, penyelenggaraan dan alat pendukung. Warga merespon dengan sangat baik dan antusias terlihat dari penilaian diatas skala 4. Hal ini karena sesuai dengan kondisi seringnya terjadi kebakaran di sekitar lokasi Desa Pasir Panjang Kelurahan Rempang Cate Kecamatan Galang. Selain itu juga program pengabdian ini memberikan hibah berupa alat pemadam kebakaran dan alat prototype IoT untuk memberikan deteksi dini bahaya kebakaran. Alat diberikan langsung kepada warga melalui Ketua RT.

\section{UCAPAN TERIMAKASIH}

Penulis mengucapkan terimakasih kepada P2M Politeknik Negeri Batam, Dinas Pemadam Kebakaran Kota Batam dan Masyarakat Desa Pasir Panjang dalam menyukseskan kegiatan pengabdian.

\section{DAFTAR PUSTAKA}

Dinas Kelautan, Perikanan, Pertanian dan Kehutanan Batam tersedia di https://arsipskpd.batam.go.id/batamkota/sk pd.batamkota.go.id/kp2k/kehutanan/klipin g-2-2/index.html [akses 22 Mei 2021]

Hakim, A., Hariyawan, M. Y., \& Widiasari, C. (2012). Pengukur Kelembaban Tanah dan Suhu Udara sebagai Pendeteksi Dini Kebakaran Hutan melalui Wireless Sensor Network (WSN) Hardware. Jurnal Aksara Elementer, 1(1).

Irawan, H., Rivai, M., \& Budiman, F. (2017). Rancang Bangun Wireless Sensor Network
Pada Pendeteksi Dini Potensi Kebakaran Lahan Gambut Menggunakan Banana Pi IoT. Jurnal Teknik ITS, 6(2), C264-C268.

Kurniawan, D. E., \& Surur, M. N. (2016). Perancangan Sistem Pengamanan Sepeda Motor Menggunakan Mikrokontroler Raspberry Pi dan Smartphone Android. Jurnal Komputer Terapan, 2(2), 93-104.

Kurniawan, D. E. (2017). Push Notification System Pada Prototype Kendali Listrik Rumah. CESS (Journal of Computer Engineering, System and Science), 2(2), 8992.

Kurniawan, D. E., Iqbal, M., Friadi, J., Borman, R. I., \& Rinaldi, R. (2019, November). Smart Monitoring Temperature and Humidity of the Room Server Using Raspberry Pi and Whatsapp Notifications. In Journal of Physics: Conference Series (Vol. 1351, No. 1, p. 012006). IOP Publishing.

Laman Website Jawa Pos tersedia di https://www.jawapos.com/read/2018/02/19/ 189876/kebakaran-mulai-landa-hutanlindung-batam [akses 21 Mei 2018]

Laman Website Kepri Online tersedia di http://keprionline.co.id/satu-permanenrumah-terbakar-di-meral-kerugianmencapai-ratusan-juta/ [akses 21 Mei 2018]

Laman Website Tribun Batam tersedia http://batam.tribunnews.com/2018/03/06/ke bakaran-hebohkan-meral-barat-saksi-matapanik-teriaki-sang-paman [akses 21 Mei 2018]

Laman Website Tribun Batam tersedia http://batam.tribunnews.com/2016/05/05/m aya-histeris-lihat-rumahnya-terbakarsayamerasa-sudah-masuk-ke-rumah-ternyatasaya-pingsan [akses 21 Mei 2018]

Pemadam Kebakaran Batam tersedia https://arsipskpd.batam.go.id/batamkota/skp d.batamkota.go.id/damkar/kontakdamkar/index.html [akses 22 Mei 2018]

Rahman, N Vinky (2004). Kebakaran, Bahaya Unpredictable, Upaya dan Kendala Penanggulangannya. Universitas Sumatera Utara.

Tersedia: 
http://repository.usu.ac.id/bitstream/handle/ 123456789/1281/arsitekturvinky8.pdf?sequence $=1 \quad$ [akses 23 Mei 2018]

Sasmoko, D., \& Mahendra, A. (2017). Rancang Bangun Sistem Pendeteksi Kebakaran Berbasis IoT dan SMS Gateway Menggunakan Arduino. Simetris: Jurnal
Teknik Mesin, Elektro dan Ilmu Komputer, 8(2), 469-476.

Sirait, D. S. P., Darlis, D., \& Santoso, I. H. (2016). Implementasi Sensor Wireless Sebagai Monitoring Serta Pendeteksi Indikator Kebakaran Hutan. eProceedings of Engineering, 3(2). 